\title{
Revisited Foreign Tourist's Perception toward Crime and Violence Issue in Bangkok, Thailand
}

\author{
Mahachai Sattayathamrongthian, Yingsak Vanpetch
}

\begin{abstract}
This research aims to examine: tourist's perceptions, the factors related to revisiting Thailand, and significant relationship between tourist's experience and duration of their stays in Thailand. The information was collected by surveying foreign tourists in Bangkok area using mixed research methodology. Quantitative Research Area was assigned to collect data from foreign tourists using a questionnaire. The participants for this study were selected through the process of accidental sampling. The samples are the 512 foreign tourists who visited Bangkok from April 1st to 30th, 2019. The study can be concluded that the most influencing factor to tourism in Thailand is the suggestions and advice received from tourist's acquaintances, which mostly give positive influences toward the decision to visit Thailand. The real advice and suggestions from tourist's acquaintances carried more influence than from other media.
\end{abstract}

Keyword: Thai tourism, tourist's perception, crime issue, international tourism, tourist decision-making.

\section{INTRODUCTION}

Over ten years ago, Thailand tourism continuously growth from less than 1 million peoples a month to over two million people a month in the present (World Travel \& Tourism Council, 2015). The acceleration in government spending and the recovery in the tourism sector are among the few bright spots supporting the economy (Oliver Holmes report, 2015).

The travel industry is one of the most significant segments driving the Thai economy, which can ceaselessly create high pay for Thailand. The number of global visitor landings to Thailand in 2018 contacted 38.12 million individuals, up 7.1 percent. Although the second half of 2018 has shown the slow pace of international tourist arrivals due to the different factors from each nationality, the number recovered during the last two months of 2018 thanks to the tourist season and the Visa on Arrival expense waved for 21 nations.

Thus, in 2018, Thailand got around THB 2.01 trillion in income from the landing of international visitors. (Kasikornbank, 2019) Unfortunately, Thailand has a moderate crime rate contrasted with different nations in Asia. This is for the most part well-behaved individuals, yet there is a great deal of medication maltreatment in the nation, and going connected at the hip with that are burglaries and frivolous wrongdoing, and every so often some genuine violations.

Table 1 - Crime index of Bangkok (source: numbeo, 2019)

\begin{tabular}{|c|c|c|}
\hline $\begin{array}{l}\text { Crime rates in Bangkok, } \\
\text { Thailand }\end{array}$ & & \\
\hline Level of crime & 41.91 & Moderate \\
\hline $\begin{array}{l}\text { Crime increasing in the past three } \\
\text { years }\end{array}$ & 58.71 & Moderate \\
\hline Worries being mugged or robbed & 39.11 & Low \\
\hline Worries attacked & 32.33 & Low \\
\hline Worries being insulted & 31.59 & Low \\
\hline $\begin{array}{l}\text { Worries being subject to a } \\
\text { physical attack because of your } \\
\text { skin color, ethnic origin or } \\
\text { religion }\end{array}$ & 20.12 & Low \\
\hline $\begin{array}{l}\text { Problem people using or dealing } \\
\text { drugs }\end{array}$ & 53.89 & Moderate \\
\hline $\begin{array}{l}\text { Problem property crimes such as } \\
\text { vandalism and theft }\end{array}$ & 43.54 & Moderate \\
\hline $\begin{array}{l}\text { Problem violent crimes such as } \\
\text { assault and armed robbery }\end{array}$ & 39.63 & Low \\
\hline Problem corruption and bribery & 83.33 & Very High \\
\hline $\begin{array}{l}\text { Safety walking alone during } \\
\text { daylight }\end{array}$ & 79.82 & High \\
\hline Safety walking alone during night & 55.48 & Moderate \\
\hline \multicolumn{3}{|c|}{$\begin{array}{c}\text { Bangkok, Thailand: The crime index is } 41.23 \text {, and the safety } \\
\text { index is } 58.77 \text { in } 2019\end{array}$} \\
\hline \multicolumn{3}{|c|}{$\begin{array}{l}\text { Caracas, Venezuela (The highest crime index): The crime } \\
\text { index is } 85.26 \text {, and the safety index is } 14.74 \text { in } 2019\end{array}$} \\
\hline \multicolumn{3}{|c|}{$\begin{array}{l}\text { Abu Dhabi, United Arab Emirates (The Lowest crime index): } \\
\text { The crime index is } 10.61 \text {, and the safety index is } 89.39 \text { in } 2019\end{array}$} \\
\hline
\end{tabular}

Contributors: 246, this data was based on perceptions of visitors of this website in the past three years. If the value is 0 , it means it is perceived as very low, and if the value is 100 , it means it is perceived as very high. Despite the crime and violence issue, the number of tourists visiting Thailand significant increased from 35.35 million in 2017 to 38.28 million in 2018.

Revised Version Manuscript Received on 16 September, 2019.

* Correspondence Author

Mahachai Sattayathamrongthian, Rajamangala University of Technology Rattanakosin, Salaya, Phutthamonthon, Nakhon Pathom, Thailand. e-mail: mahachai.sat@rmutr.ac.th

Yingsak Vanpetch (corresponding author), International College, Suan Sunandha Rajabhat University, Dusit, Bangkok, Thailand e-mail:yingsak.va@ssru.ac.th 
Thailand Tourists arrivals during 2011-2018

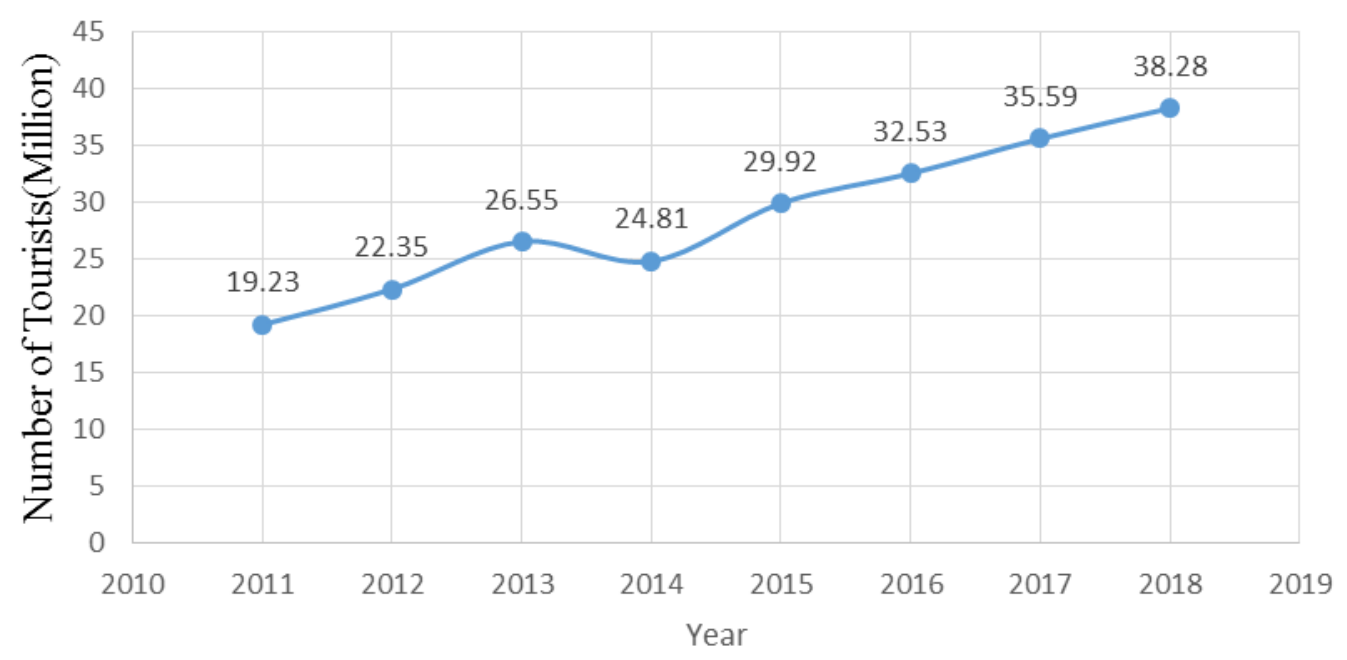

Figure 1 Thailand Tourists arrivals during 2011-2018 (source: Ministry of Tourism and Sport, 2018)

\section{RESEARCH OBJECTIVES}

1. To observe the revisited tourists' perception toward crime and violence issueand the factors related to the decision to revisit Thailand.

2. To examine the relationship between general tourists' perception, duration of stay in Thailand, and the travel experience.

\section{LITERATURE REVIEW}

The researchers apply a Model of the Pleasure Travel Destination Choice Process based on Um and Crompton Pizam, A. and Manfield, Y. (2000); Andreeva et al. (2016, 2017); Ushakov (2015).

External inputs have consisted of three components: symbolic stimuli, experience stimuli, and social stimuli, including general attitude toward the terrorist situation, which create a set of awareness in selecting the travel destination.

Internal factors are psychological factors of the tourist, such as motive, attitude toward something, value, and personal characteristic. These factors significantly affect the decision making and initiation of choices.

The internal factors will naturally create consideration of alternative destination choices, where individuals will compare their perceptions of each country before making a decision. Furthermore, the evolution of an evoked set, the tourists carefully consider destinations by compare and contrast between possible destinations, time of staying, safety issue, and all in-depth information.

According to Gabriela M. Grando (2015), when compare and contrast between two destinations with similar benefits, but with a threat to one, individuals would choose the less costly option that is perceived to be safe from a possible threat. Sonmez and Graefe (1998a, p. 118) stated that tourist decision making might be interrupted when risk is introduced as a factor in destination choices.

\section{RESEARCH METHODS}

After the literature review and conceptualization of the research structure, the researchers decided to employ the following research methods to obtain data for the study:

\section{Quantitative Method}

The quantitative research area was assigned to collect data from foreign tourists using a questionnaire. The participants for this study were selected through the process of accidental sampling. The samples are the 512 foreign tourists who were visiting Bangkok from April $1^{\text {st }}$ to $30^{\text {th }}$, 2019 (W.G Cochan, 1953). The advisors reviewed the questionnaire from the Rajamangala University of Rattanakosin and as well as other researchers.

Part One: The personal information includes gender, age, marriage status, education, and nationality.

Part Two: The tourist behaviors: spending, expected time to stay in Thailand, factors related to visiting decision, problems during the trip and tourist's satisfaction

Part Three: Overall satisfaction includes revisiting decision, expectation, and recommendation to another interested tourist.

\section{Qualitative Research}

The qualitative research method was employed to collect data from foreign tourists in Bangkok tourist attraction: Grand Palace, Khaosarn Road, Silom, Siam Centre, and in the front of Central World. This part of the research data was obtained through the personal interviews conducted on the tourists. A typical interview is more than simply asking questions and receiving responses; the goal is to create a safe and open dialogue whereby the participant may authentically discuss his or her experiences or meanings. The topics are the reasons why they want to visit Thailand, the influential source of information, their perceived risk before and after visitingthe country.

The breakdown of the participants' is as follow: 
Table 1: Research participants 'ethnicities

\begin{tabular}{|c|c|c|c|c|c|}
\hline No & Gender & age & nationality & Total Visiting & Purpose \\
\hline 1 & male & 25 & Chinese & 3 & Vacation \\
\hline 2 & female & 27 & American & 2 & Vacation \\
\hline 3 & male & 41 & Sweden & 2 & Vacation \\
\hline 4 & female & 45 & Sweden & 2 & Vacation \\
\hline 5 & male & 22 & American & 4 & Vacation \\
\hline 6 & female & 50 & Japanese & 2 & business \\
\hline 7 & male & 55 & American & 5 & Vacation \\
\hline 8 & female & 38 & American & 4 & business \\
\hline 9 & male & 35 & American & 2 & business \\
\hline 10 & female & 51 & British & 2 & Vacation \\
\hline 11 & male & 38 & Sweden & 2 & Vacation \\
\hline 12 & female & 26 & Chinese & 5 & business \\
\hline 13 & male & 28 & Chinese & 4 & business \\
\hline 14 & female & 28 & Chinese & 5 & Vacation \\
\hline 15 & female & 31 & Indonesia & 3 & \\
\hline
\end{tabular}

\section{RESUlt}

The following are the results of the research study using qualitative and quantitative data gathering methods. Table 2 - Demographic of questionnaire respondents

\begin{tabular}{|c|c|c|c|}
\hline & & Frequency & Percent \\
\hline & Male & 213 & 41.6 \\
\hline Gender & Female & 299 & 58.4 \\
\hline & Total & 512 & 100 \\
\hline Age & $0-15$ & 33 & 6.45 \\
\hline & $16-30$ & 233 & 45.51 \\
\hline & $31-45$ & 158 & 30.86 \\
\hline & $46-60$ & 56 & 10.94 \\
\hline & $61 \& u p$ & 32 & 6.25 \\
\hline Marital Status & Total & 512 & 100 \\
\hline & Single & 252 & 57.8 \\
\hline & Married & 245 & 38.3 \\
\hline & Separated & 15 & 3.4 \\
\hline & Total & 512 & 100 \\
\hline
\end{tabular}

Most of the participant is female, age between 16-30, and single.

Table 3 - Respondents' nationality and educational background

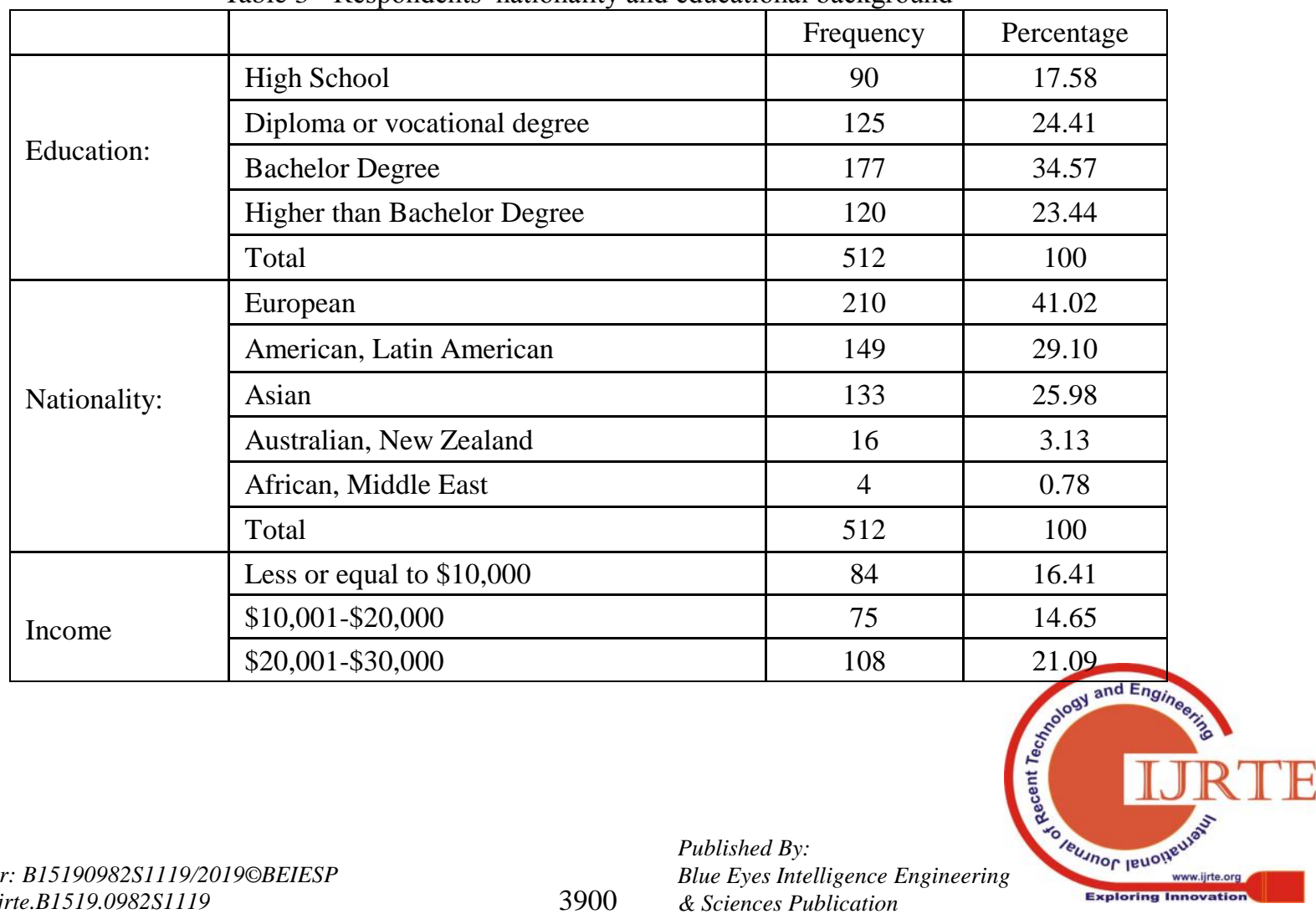




\begin{tabular}{|l|l|c|c|}
\hline & $\$ 30,001-\$ 40,000$ & 97 & 18.95 \\
\cline { 2 - 4 } & $\$ 40,001-\$ 50,000$ & 85 & 16.60 \\
\cline { 2 - 4 }$\$ 50,001$ and over & 19 & 3.71 \\
\cline { 2 - 4 } & Missing info & 44 & 8.59 \\
\cline { 2 - 4 } & Total & 512 & 100 \\
\hline
\end{tabular}

The respondents' average annual income data revealed that the incomes could be distributed into almost every income group. This means that the tourists are from various income levels.

Table 4 - The number of times the respondents' have visited Thailand

\begin{tabular}{|l|c|c|}
\hline Time visiting Thailand & Frequency & Percentage \\
\hline First time & 287 & 56.05 \\
\hline More than 1time & 225 & 43.95 \\
\hline Total & 512 & 100.0 \\
\hline
\end{tabular}

From the data collected, most of the participating tourists have visited Thailand for the first time, as high as $56.05 \%$, while $43.95 \%$ of the respondents have visited Thailand more than once before.

Table 5 - Factors related to respondents' tourist destination visiting decision

\begin{tabular}{|l|c|c|c|c|}
\hline & $\mathrm{N}$ & Mean & Sd & Significant level \\
\hline Thai Culture and Lifestyle & 512 & 4.2431 & .87433 & Extremely influential \\
\hline Cost of living in Thailand & 512 & 3.5814 & 1.07162 & Very influential \\
\hline Thai Food & 512 & 3.9136 & 1.11389 & Very influential \\
\hline Safety issue & 512 & 3.1077 & 1.17754 & Moderately influential \\
\hline Thai Good and Souvenir & 512 & 2.8518 & 1.28458 & Moderately influential \\
\hline Nightlife & 512 & 2.7629 & 1.29165 & Moderately influential \\
\hline Tourism Campaign & 512 & 2.6564 & 1.28501 & Moderately influential \\
\hline Education or Training & 512 & 2.2759 & 1.36203 & Slightly influential \\
\hline Business opportunity & 512 & 2.0986 & 1.27774 & Slightly influential \\
\hline
\end{tabular}

Table 7 demonstrate that the top three factors related to tourists' visiting decision are Thai Culture and Lifestyle, Cost of living in Thailand and Thai Food. Surprisingly, the safety issue only has moderate influent on the tourists' visiting decision.

Table 6 - Problems and concerns for tourists during the visit

\begin{tabular}{|l|c|c|c|c|}
\hline \multicolumn{1}{|c|}{ Problems } & $\mathrm{N}$ & Mean & Std. Dev. & Frequency Level \\
\hline Transportation and Traffic & 512 & 3.3179 & 1.04931 & Sometime \\
\hline Dirty and bad sanitation & 512 & 2.9722 & .95084 & Sometime \\
\hline Price of goods and services & 512 & 2.4186 & 1.09529 & Rarely \\
\hline Scams on tourist & 512 & 2.3357 & 1.22060 & Rarely \\
\hline Safety issue and robbery & 512 & 2.2581 & 1.13469 & Rarely \\
\hline Accommodation & 512 & 2.2181 & 1.12219 & Rarely \\
\hline Immigration & 512 & 2.1831 & 1.04905 & Rarely \\
\hline Local Thai people & 512 & 2.1465 & 1.16852 & Rarely \\
\hline Tourist information officer & 512 & 2.0935 & 1.16774 & Rarely \\
\hline Thai Tourist Guide & 512 & 2.0939 & 1.19828 & Rarely \\
\hline Law enforcement & 512 & 1.9743 & 1.06104 & Rarely \\
\hline Crime & 512 & 1.8519 & 1.05368 & Rarely \\
\hline
\end{tabular}

The research data indicated that transportation and traffic problem and dirty sanitation are perceived by foreign tourists to be more significant concerns. Crime is the least concerns when tourists visit Thailand.

Table 7 - Tourists' satisfaction

\begin{tabular}{|l|c|c|}
\hline Tourist Satisfaction & Frequency & Percentage \\
\hline Better than expectation & 290 & 56.6 \\
\hline Same as expectation & 179 & 34.96 \\
\hline
\end{tabular}




\begin{tabular}{|l|c|c|} 
Worse than expectation & 43 & 8.3 \\
\hline Total & 512 & 100 \\
\hline
\end{tabular}

Table 8: Tourists' revisiting decision

\begin{tabular}{|l|l|l|}
\hline Revisiting decision & Frequency & Percentage \\
\hline Yes & 430 & 83.98 \\
\hline No & 15 & 3.5 \\
\hline Not sure & 50 & 9.7 \\
\hline Missing & 17 & 3.32 \\
\hline Total & 512 & 100 \\
\hline
\end{tabular}

Overall, most of the foreign tourists' satisfaction is considerably kind, and most of them would consider revisiting Thailand for vacation again.

Table 9: Tourists' estimated spending during the duration of stay

\begin{tabular}{|l|c|c|c|c|c|}
\hline & $\mathrm{N}$ & Minimum & Maximum & Mean & Std. Deviation \\
\hline Spending & 458 & 100.00 & 12000.00 & 1866.1648 & 1855.57351 \\
\hline \multicolumn{7}{|l|}{} \\
\hline & $\mathrm{N}$ & Minimum & Maximum & Mean & Std. Deviation \\
\hline Average Spending/day & 458 & 1.11 & 2500.00 & 166.5607 & 272.63528 \\
\hline
\end{tabular}

A typical foreign tourist spends on the average of 1866.1648 USD per visit and spends 166.56 USD per day on average.

Table 10 - Tourists' perception toward Thailand and the crime issue incident

\begin{tabular}{|l|c|c|c|c|c|}
\hline & Symbol & $\mathrm{N}$ & Mean & Std. Deviation & Significant level \\
\hline 1. How well do you know Thailand? & Knw & 478 & 2.554 & 1.25637 & Fair \\
\hline $\begin{array}{l}\text { 2. Will the crime issue in Bangkok make you } \\
\text { less likely to visit Thailand? }\end{array}$ & Prob1 & 493 & 2.554 & 1.25183 & Slightly Influential \\
\hline $\begin{array}{l}\text { 3. Will fraud on tourist affect your decision in } \\
\text { visiting Thailand? }\end{array}$ & Prob2 & 473 & 3.108 & 1.29448 & Moderately Influential \\
\hline $\begin{array}{l}\text { 4. Will safety issue affect your decision in } \\
\text { visiting Thailand? }\end{array}$ & Prob3 & 494 & 3.145 & 1.30716 & Moderately Influential \\
\hline
\end{tabular}

Safety issue and cheating on tourist are moderately influent the tourist's perception towards visiting Thailand. The crime issue in Bangkok slightly influences the tourist's perception of visiting Thailand. Tourists concerns about general traveling safety issues more than the safety raised by the crime issue incident in Bangkok.

Multiple Regression Equation:

$\mathrm{Y}=\mathrm{a}+\mathrm{b}_{1} * \mathrm{X}_{1}+\mathrm{b}_{2} * \mathrm{X}_{2}+\ldots+\mathrm{b}_{\mathrm{n}} * \mathrm{X}_{\mathrm{n}}+\mathrm{e}$

The first multiple regression analyses were conducted to examine the relationship between various tourists' perceptions of the current problems in Thailand and the duration of stay in Thailand.

Staying $=20.106+\quad 6.060 \quad$ Knw-3.869Prob1 4.327Prob3+e
$T$ value
(3.608) (-1.983) (-2.231)

$\mathrm{R}=.253 \mathrm{R}^{2}=0.058 \mathrm{SEE}=35.122 \mathrm{~F}=4.959 \mathrm{Sig}$ of $\mathrm{F}=$
Having a better knowledge and understanding of the real situation in Thailand positively affects tourists' duration of stay in the country. The multiple regression analysis indicates that with one scale of knowledge about Thailand would increasethe duration of stay by six days.The crime and violence issue created a negative effect on foreign tourists' duration of stay. According to the equation concerning the bombing incident and safety issue concerns, one scale of influence would decrease the duration of stays of the foreign tourists by four and five days, respectively. Consequently, this equation can be applied to $5.8 \%$ of foreign tourists.

The second multiple regression analyses were conducted to examine the relationship between foreign tourist's spending and the duration of stay for foreign tourists in Thailand.

$$
\begin{aligned}
& \text { Spending }=1,343.725+26.992 \text { Stay }+e \\
& T \text { value }=6.818 \\
& R=0.342 \mathrm{R}^{2}=0.114 \mathrm{SEE}=1752.872 \mathrm{~F}=46.491 \mathrm{Sig} \text { of } \mathrm{F}
\end{aligned}
$$$$
=0.000
$$
0.000 
The foreign tourists' duration of stay positively affects the tourist's spending; indicating that one day of staying in Thailand significant increases tourist's spending by an estimate of 26.992 USD. This equation can use utilized to make the predictions $11.4 \%$ of foreign tourists.

\section{Conclusion}

\section{Tourist's perception and the factors related to visiting Thailand}

Among many factors that play a significant role in appealing elements for tourists' demand and choosing to travel toward the particular destination, the top three factors related to tourist's visiting decision are Thai culture and lifestyle, cost of living in Thailand and Thai Food. Surprisingly, the safety issue only moderately influences the tourist's visiting decision despite the tragedy. David Scowsill (The nation, 2015), president and chief executive officer of the World Travel and Tourism Council. "When any country gets hit, it follows the same pattern. The government makes an effort to rebuild the travel industry, and once the incident disappears from the media, forgotten, and tourists will return."

According to the short-interviews, all of the tourists participated in the interview consider the crime and violence and safety issue as a moderate influential factor related to their Thailand visiting decision. The American tourists expressed that they felt comfortable during their visits and were planning to go to Phuket the week after. The Swedish tourists had planned to visit Thailand four months ago. After he saw the news about the murder case on the internet, he had collected all the related information on the internet, social media, and still decided to visit Thailand. They came to Thailand because of the reviews they found on the internet and the recommendations from friends. The Chinese and British tourists perceived risk in Bangkok is relatively low. One of the British tourists was working in Bangkok four years ago and came back to visit during his vacation time.

Moreover, according to the South China Morning Post report on August $19^{\text {th }}$ (South China Morning Post website, 2015), the journalists were present at the site to interview the tourists. Most of the tourists felt comfortable to visit them despite the crime issue. The question of whether or not the crime issue has major influential factors on tourists' decision to visit Thailand cannot be concluded. This is because the tourists that consider crime incident as an extreme influent to their decisions may not be in Thailand or maybe not available during this research study.

Information from people's suggestions, social stimulus and internet are very influential to the foreign tourist's decision. The overall foreign tourist's satisfactions are considerably good, creating a positive impression on social stimulus, which, in turn, would pass on the information through the internet, social media, and other channels. However, transportation infrastructure problems, congested traffic condition, dirty and lousy sanitation are still considered to be of significant concerns and require improvement.

The external inputs are significantly affected by the set of awareness. However, regarding to tourist's revisiting decision, $83.98 \%$ of tourists want to revisit Thailand, and the fear of explosion slightly impacts the first stage of selecting travel destination, according to Gilham (2001), because the chances of being killed or injured as a result of terrorist activity are considered to be very small, low perceived risk.

The study result demonstrates that thecrime tragedy appears only to have a short-term impact on tourism of Thailand. Tourists may perceive a destination to be risky but not necessary to worry about going there (Larsen et al., 2009). The foreign tourists might not recognize the probabilities of risk (Williams and Baláž, 2014) and pay more attention to the devices of their acquaintances more than other media. The proportions of those who want to return to Thailand were also higher.

\section{RECOMMENDATION FOR FURTHER RESEARCH}

Further researches should focus on other national and international studies comparing normal circumstances.It is more effective to hire interpreters to accompany the research group to help to translate and communicating with foreign tourists when collecting data onsite. The data would have been more diverse if the sample group can be expanded to include tourist who has been to Thailand before the major crime incident.

\section{ACKNOWLEDGMENT}

Thanks to the Rajamangala University of Technology Rattanakosin and Suan Sunandha Rajabhat University for all of the supports for this research.

\section{REFERENCES}

1. Andreeva, E. et al. (2016). Internal regional and demographic tourists' inflows distribution as factor of national tourism competitiveness. Actual Problem of Economics, 9

2. Andreeva, E. et al. (2017). Evaluation Of Resorts' Capacity As A Factor For Regional Tourists' Traffic Planning. Actual Problem of Economics, 4.

3. Cendrowski, S. (2015).Tourist Arrivals, Even in a Slowing Global Economy. Trading Economics, Retrieved January 6, 2016, from http://www.tradingeconomics.com/thailand/tourist-arrivals, even in a slowing global economy

4. Fredman, P. (2008). Determinants of Visitor Expenditures in Mountain Tourism. Tourism Economics 14(2), 297-311.

5. Gilham, R. (ed) (2001). Tourism and the Media, Australia, Hospitality Press Pty Ltd

6. Granado, Gabriela M. (2015). Terrorism risk in Mexico and the impact on tourism discourse. Retrieved December 24, 2015, from http://search.proquest.com/docview/1722472666

7. Holmes, O. (2015, August 18). Tourists Return to Bangkok Blast Area Amid Gears for Vital Industry. Retrieved from http://www.theguardian.com/world/2015/aug/18/tourists-return-to-ba ngkok-blast-area-amid-fears-for-vital-industry

8. kasikornbank. (2019). Retrieved from kasikornbank.com https://kasikornbank.com/international-business/en/Thailand/Industry Business/Pages/201901_Thailand_TourismOutlook19.aspx

9. Larsen, S., Brun, W., \&Øgaard, T. (2009). What tourists worry about Construction of a scale measuring tourist worries. Tourism Management, 30(2), 260-265. DOI http://dx.doi.org/10.1016/j.tourman.2008.06.004

10. Ministry of Tourism and Sport (2018). Tourism statistics. https://www.mots.go.th/more_news.php?cid=411

11. numbeo. (2019). Retrieved from numbeo: https://www.numbeo.com/crime/in/Bangkok

12. Pizam, A., \& Manfield, Y. (2000).Consumer Behavior in Travel and Tourism. New York, The Haworth Hospitality Press, Inc., 16

13. Reflections. Journal of Travel Research. DOI: $10.1177 / 0047287514523334$ 
14. Sonmez and Graefe (1998).Influence of Terrorism Risk on Foreign Tourism Decisions.Annuals of Tourism Research, 25(1), 118

15. Ushakov, D. et al. (2016). Transnationalization as a trend of the present stage of international tourism development. Actual Problem of Economics, 2.

16. Williams, A. M., \&Baláž, V. (2014). Tourism Risk and Uncertainty: Theoretical

17. World Travel \& Tourism Council (2015).Travel \& Tourism Economic Impact, 2015. Retrieved January 3, 2016, from https://www.wttc.org 